\title{
ANALISIS SISTEM PENGENDALIAN INTERNAL PADA SISTEM AKUNTANSI PEMERINTAH (STUDI KASUS PADA DINAS KOMUNIKASI DAN INFORMATIKA KABUPATEN SEMARANG)
}

\author{
Irma Damayanti, Siti Afidatul Khotijah* \\ Program Studi S1 Akuntansi Fakultas Ekonomi, Universitas Tidar \\ *e-mail: irmadama47@gmail.com, khotijah afi@untidar.ac.id
}

\begin{abstract}
The aim of this study is to analyze the appropriateness of the application of the internal control system carried out at government agencies based on the elements of internal control. The analysis uses descriptive research method and the type of research used is qualitative research. The object of this research is the Ministry of Communication and Information of Semarang Regency. The result shows that the application of the internal control system in the Ministry of Communication and Information of Semarang Regency is in accordance with the elements of the Internal Control System set by the government based on the Government Regulation No. 60 year 2008, but there are some deficiencies such as the number of students internships received exceeds the limit, some employees who perform the main duties of supervision, budgeting, and planning do not have economic education background especially accounting, and warehouse facility provided for documents and belongings are not efficient.
\end{abstract}

Keywords: Internal Control System, Ministry of Communication and Information of Semarang Regency, public sector accounting

Abstrak

Penelitian ini bertujuan untuk menganalisis kesesuaian penerapan sistem pengendalian internal yang dilakukan pada instansi pemerintahan berdasarkan dengan unsur-unsur pengendalian intern. Analisis dilakukan menggunakan metode penelitian deskriptif dengan jenis penelitian yang digunakan adalah penelitian kualitatif. Objek penelitian ini adalah Dinas Kominfo Kabupaten Semarang. Hasil penelitian menunjukkan penerapan sistem pengendalian internal di Dinas Kominfo Kabupaten Semarang telah sesuai dengan unsur-unsur dalam Sistem Kontrol Internal yang telah ditetapkan oleh pemerintah berdasarkan Peraturan Pemerintah No. 60 tahun 2008 tetapi masih ada beberapa kelemahan seperti kelebihan siswa magang yang diterima, tidak semua pegawai yang melakukan tugas pokok pengawasan, penganggaran dan perencaraan berlatar belakang pendidikan ekonomi, khususnya akuntansi, dan fasilitas gudang untuk dokumen dan barang-barang yang kurang efisien.

Kata Kunci : Sistem Pengendalian Intern, Dinas Kominfo Kabupaten Semarang, Akuntansi Sektor Publik

\section{PENDAHULUAN}

Pemerintah harus melaksanakan sistem pengendalian dalam organisasi agar mendapatkan kinerja pemerintahan yang baik dan dapat menciptakan good governance. Berkaitan dengan sektor pemerintahan, pendekatan dari sistem pengendalian intern pada Pemerintah Pusat dan daerah berpedoman pada Sistem Pengendalian Intern Pemerintah (SPIP) yang didasarkan pada Peraturan Pemerintah Nomor 60 Tahun 2008. Dalam Ketentuan Umum pasal 1 angka 2, Sistem Pengendalian Intern diselenggarakan secara menyeluruh di lingkungan pemerintah pusat dan pemerintah daerah. Sistem pengendalian intern sangat penting dalam menunjang perbaikan pengelolaan pemerintah daerah dan faktor pendukung untuk menciptakan pemerintahan yang akuntanbel dan transparan sebagai bentuk kinerja yang baik.

Pengendalian intern adalah rencana organisasi dan metode yang digunakan untuk menjaga atau melindungi aktiva, menghasilkan informasi yang akurat dan dapat dipercaya, memperbaiki efisiensi dan mendorong ditaatinya kebijakan manajemen (Krismiaji, 2010:218). Setiap kegiatan dan tindakan yang dilakukan secara terus menerus untuk mencapai tujuan organisasi melalui kegiatan yang efektif dan efisien. Pengendalian intern tidak hanya memeriksa kebenaran angka-angka, tetapi juga memperhatikan struktur organisasi perusahaan/instansi, meningkatkan efisiensi kinerja dan menganalisis keberhasialan dari suatu kebijakan manajemen. Maka dari itu, pengendalian intern harus dimonitor dan dievaluasi agar manfaat dari 
pengendalian intern tersebut berhasil serta dapat dipertanggungjawabkan.

Upaya mewujudkan visi, Dinas Kominfo Kabupaten Semarang perlu adanya pengendalian internal. Dalam pelaksanaannya pasti Dinas Kominfo Kabupaten Semarang sendiri dihadapkan dengan berbagai kendala atau permasalahan. Peneliti sebelumnya telah membahas penerapan sistem pengendalian internal. Dalam penelitiannya, Ismani, et al. (2014) yang berjudul Implementasi sistem pengendalian intern pemerintah di Universitas Negeri Yogyakarta, menyatakan bahwa implementasi unsur-unsur Sistem Pengendalian Intern Pemerintah di UNY sudah berjalan dengan baik. Hamidah (2014) dalam penelitian yang berjudul Pengaruh pelaksanaan sistem pengendalian intern pemerintah dan sumber daya manusia terhadap pengamanan aset negara. Hasil penelitian menunjukkan terdapat pengaruh yang signifikan dan positif penerapan SPIP dan sumber daya manusia terhadap pengamanan aset negara. Dimana semakin baik penerapan SPIP dan sumber daya manusia maka pengamanan aset negara pun akan semakin baik.

Penelitian diatas mengarah pada penerapan unsur-unsur SPIP yang diatur dalam PP Nomor 60 Tahun 2008 yang meliputi lingkungan pengendalian, penilaian risiko, kegiatan pengendalian, informasi dan komunikasi, serta pemantauan pengendalian intern. Data-data mengenai apakah unsur-unsur tersebut sudah diterapkan pada Dinas Kominfo Kabupaten Semarang menggunakan metode survey dengan angket. Penelitian kali ini juga berusaha mengetahui dan menganalisis penerapan SPIP di Dinas Kominfo Kabupaten Semarang, akan tetapi dalam memperoleh informasi dalam penelitian ini dilakukan dengan metode observasi dan wawancara. Penelitian ini dilaksanakan agar dapat mengetahui bahwa pengendalian internal itu penting dalam setiap organisasi. Tujuan dari penelitian ini adalah untuk mengetahui serta menganalisis kesesuaian pelaksanaan sistem pengendalian internal yang dilakukan oleh Dinas Kominfo Kabupaten Semarang berdasarkan unsur-unsur pengendalian internal.

\section{TINJAUAN PUSTAKA Akuntansi Sektor Publik}

terdiri dari mencatat, mengklasifikasikan, dan melaporkan kejadian atau transaksi ekonomi yang akhirnya akan menghasilkan suatu informasi keuangan yang akan dibutuhkan oleh pihak-pihak tertentu untuk pengambilan keputusan(Sujarweni, 2015:1). Fungsinya untuk menyajikan informasi kuantitatif, terutama yang bersifat keuangan dari lembaga ekonomi dengan tujuan agar berguna untuk pengambilan keputusan ekonomis, yakni pilihan yang terbaik diantara berbagai alternatif tindakan yang ada (Harahap, 2004;5). Karakteristik organisasi sektor publik yang utama adalah bersifat nonprofit (nonlaba). Tujuan dari organisasi sektor publik hanyalah memberikan pelayanan kepada publik (masyarakat) dan meningkatkan kesejahteraannya. Akuntansi sektor publik berbeda dengan sektor swasta menurut lingkungan yang mempengaruhi, organisasi sektor publik bergerak dalam lingkungan yang kompleks.

Akuntansi sektor publik dapat didefinisikan sebagai aktivitas jasa yang terdiri dari mencatat, mengklasifikasikan dan melaporkan kejadian atau transaksi ekonomi yang akhirnya akan menghasilkan suatu informasi keuangan yang akan dibutuhkan oleh pihak-pihak tertentu sebagai pengambilan keputusan yang diterapkan pada pengelolaan dana publik di lembaga tinggi negara dan departemen dibawahnya (Sujarweni, 2015:1). Organisasi sektor publik dipengaruhi oleh faktor ekonomi, politik, budaya, dan demografi.

Ada beberapa jenis akuntansi yang merupakan bagian dari akuntansi sektor publik, salah satunya adalah akuntansi pemerintahan. Menurut Deddi, dkk. (2012:1) akuntansi pemerintahan adalah aplikasi akuntansi di bidang keuangan negara, khususnya pada tahapan pelaksanaan anggaran, termasuk segala pengaruh yang ditimbulkannya, baik yang bersifat seketika maupun yang lebih permanen pada semua tingkatan dan unit pemerintahan. Untuk menghasilkan laporan keuangan sektor publik yang relevan dan dapat diandalkan, terdapat beberapa kendala yang dihadapi akuntansi sektor publik. Hambatan tersebut adalah 1). objektivitas yang merupakan kendala utama dalam menghasilkan laporan keuangan yang relevan, sering terjadi masalah yang disebabkan karena benturan kepentingan; 2). Konsistensi yang menggunakan metode akuntansi sama untuk menghasilkan laporan selama beberapa periode waktu secara berturut-turut; 3). Laporan 
keuangan hendaknya dapat dibandingkan antar periode waktu dan dengan instansi lain yang sejenis; 4). Laporan harus disajikan tepat waktu agar dapat digunakan sebagai dasar pengambilan keputusan; 5). Ekonomis dalam penyajian laporan; dan 6). Materialitas.

\section{Sistem Pengendalian Intern}

Peraturan pemerintah Republik Indonesia No. 60 Tahun 2008, Sistem Pengendalian Intern adalah proses yang integral pada tindakan dan kegiatan yang dilakukan secara terus menerus oleh pimpinan dan seluruh pegawai untuk memberikan keyakinan memadai atas tercapainya tujuan organisasi melalui kegiatan yang efektif dan efisien, keandalan laporan keuangan, pengamanan aset negara, dan ketaatan terhadap peraturan perundang-undangan. Pengawasan Intern termasuk salah satu bagian dari pengendalian Intern yang berfungsi melakukan penilaian independen atas pelaksanaan tugas dan fungsi Instansi Pemerintah.

Mulyadi (2001:183), mendefinisikan sistem pengendalian internal meliputi struktur organisasi, metode dan ukuran-ukuran yang dikoordinasikan untuk menjaga kekayaan organisasi, mengecek ketelitian dan keandalan data akuntansi, mendorong efisiensi dan mendorong dipatuhinya kebijakan manajemen. Rama dan Jones (2008) yang diterjemahkan oleh M. Slamet Wibowo menjelaskan, pengendalian internal (internal control) adalah suatu proses, yang dipengaruhi oleh dewan direksi entitas, manajemen dan personel lainnya, yang dirancang untuk memberikan kepastian yang beralasan terkait dengan pencapaian sasaran kategori sebagai berikut: efektivitas dan efisiensi operasi, keandalan pelaporan keuangan, dan ketaatan terhadap hukum dan peraturan yang berlaku. Pengendalian internal adalah suatu proses yang dapat dipengaruhi manajemen dan karyawan dalam menyediakan secara layak suatu kepastian mengenai prestasi yang diperoleh secara objektif dalam penerapannya tentang bagian laporan keuangan yang dapat dipercaya, diterapkannya efisiensi dan efektivitas dalam kegiatan operasional perusahaan dan diterapkannya peraturan dan hukum yang berlaku agar ditaati oleh semua pihak.

Berdasarkan beberapa pengertian pengendalian internal, terdapat beberapa konsep dasar yaitu, pengendalian internal merupakan suatu proses atau rangkaian tindakan menjadi bagian yang tidak terpisahkan. bukan sebagai tambahan. dari infrastruktur entitas untuk mencapai tujuan tertentu. Pengendalian internal bukan hanya berbentuk kebijakan manual saja tetapi merupakan orang pada berbagai tingkatan organisasi, termasuk dewan direksi, manajemen, dan personel lainnya. Pengendalian internal dapat diharapkan untuk menyediakan hanya keyakinan yang memadai. Maksudnya yaitu bukan keyakinan yang mutlak, kepada manajemen dan dewan direksi suatu entitas karena keterbatasan yang melekat dalam semua sistem 10 pengendalian internal dan perlunya untuk mempertimbangkan biaya dan manfaat relative dari pengadaan pengendalian. Pengendalian internal diarahkan pada pencapaian tujuan yang saling berkaitan antara pelaporan keuangan, kepatuhan, dan operasi.

AICPA (American Institute of Certified Public Accountants) (1982), menyatakan Pengendalian Intern itu meliputi struktur organisasi dan semua cara-cara serta alat-alat yang dikoordinasikan yang digunakan di dalam perusahaan dengan tujuan untuk menjaga keamanan harta milik perusahaan, memeriksa ketelitian dan kebenaran data akuntansi, memajukan efisiensi di dalam usaha, dan membantu mendorong dipatuhinya kebijakan manajemen yang telah ditetapkan lebih dahulu. Definisi di atas menunjukkan bahwa suatu sistem pengendalian intern yang baik itu akan berguna untuk menjaga keamanan harta milik suatu organisasi, dapat memberikan ketelitian dan kebenaran data akuntansi, sistem pengendalian intern juga dapat, memajukan efisiensi dalam operasi suatu organisasi dan membantu menjaga agar tidak ada yang menyimpang dari kebijakan manajemen yang telah ditetapkan lebih dahulu.

\section{Sistem Pengendalian Internal Pemerintah (SPIP)}

Sistem Pengendalian Intern adalah proses yang integral pada tindakan dan kegiatan yang dilakukan secara terus menerus oleh pimpinan dan seluruh pegawai untuk memberikan kayakinan memadai atas tercapainya tujuan organisasi. Sistem Pengendalian Intern Pemerintah yang selanjutnya disingkat SPIP, adalah Sistem Pengandalian Intern yang diselengarakan secara menyeluruh di lingkungan pemerintah pusat dan pemerintah daerah. Berdasarkan pengertian diatas maka dapat disimpulkan bahwa SPIP meliputi metode dan kebijakan yang terkoordinir di dalam negara untuk mengamankan kekayaan negara, menguji ketepatan, 
ketelitian dan keandalan catatan serta mendorong ditaatinya kebijakaan secara menyeluruh. Adapun unsur pengendalian intern pemerintah terdiri dari a). lingkungan pengendalian; b) penilaian risiko; c) kegiatan pengendalian; d) informasi dan komunikasi; dan e) pemantauan pengendalian internal.

Lingkungan pengendalian merupakan kondisi dalam instansi pemerintah yang dapat membangun kesadaran semua personil akan pentingnya pengendalian intern dalam menjalankan aktivitas yang menjadi tanggung jawabnya. Dengan adanya penilaian risiko, instansi dapat mengidentifikasi kendala/hambatan baik internal maupun eksternal yang akan mempengaruhi tercapainya tujuan, melakukan analisis serta menentukan langkahlangkah antisipasinya. Kegiatan Pengendalian merupakan tindakan yang diperlukan untuk mengatasi risiko, penetapan dan pelaksanaan kebijakan serta prosedur untuk memastikan bahwa tindakan mengatasi risiko telah dilaksanakan secara efektif. Informasi-informasi yang diterima harus mampu disaring oleh Instansi Pemerintah untuk menjaring informasi yang relevan dan dapat diandalkan. Informasi tersebut kemudian perlu dikomunikasikan untuk mendapat umpan balik. Untuk itu dibutuhkan komunikasi yang efektif. Pemantauan sistem pengendalian intern adalah suatu proses penilaian kualitas kinerja pengendalian intern dalam suatu periode tertentu.

Tujuan dari SPIP menurut Peraturan Pemerintah Nomor 60 Tahun 2008 pasal 2 (ayat 3), yaitu untuk memberikan keyakinan yang memadai bagi tercapainya efektivitas dan efisiensi pencapaian tujuan penyelenggaraan pemerintahan negara, memberikan keandalan pelaporan keuangan, untuk menjamin pengamanan aset negara, dan ketaatan terhadap peraturan perundang-undangan. Kelima unsur SPIP menjadi fokus yang harus diperhatikan bagi Dinas Kominfo Kabupaten Semarang dalam mencapai tujuan umumnya, tujuan unit, dan tujuan tingkat kegiatan. Penerapan SPIP dalam lingkup Dinas Kominfo Kabupaten Semarang diharapkan dapat meningkatkan akuntabilitasnya dikemudian hari. Tujuan khusus yang ingin dicapai dalam penelitian ini adalah untuk mengetahui bagaimana penerapan lingkungan pengendalian, penilaian risiko, kegiatan pengendalian, informasi dan komunikasi, serta pemantauan pengendalian intern di Dinas Kominfo Kabupaten Semarang. Penelitian ini diharapkan dapat memberi kontribusi kepada pimpinan instansi mengenai unsur-unsur SPIP yang masih perlu mendapat perhatian sehingga Dinas Kominfo Kabupaten Semarang di kemudian hari tetap dapat meningkatkan pengendaliannya.

\section{METODE PENELITIAN}

Penelitian yang digunakan penulis menggunakan pendekatan kualitatif yang bersifat deskriptif, dengan cara mengumpulkan data yang berhubungan dengan permasalahan yang dihadapi. Sumber data yang digunakan penulis dalam penyusunan adalah data primer, yang diperoleh dengan metode observasi dan wawancara yang dilakukan pada instansi pemerintah khususnya pada Dinas Komunikasi dan Informatika. Data Primer adalah data asli yang dikumpulkan sendiri oleh penulis untuk menjawab penelitiannya secara khusus (Suliyanto; 2017).

Penelitian ini dilaksanakan pada Dinas Komunikasi dan Informatika Kabupaten Semarang. Pemilihan objek penelitian ini dengan pertimbangan lokasi berada di Kabupaten Semarang, dimana penulis tinggal sehingga waktu dapat dimanfaatkan secara efisien. Waktu yang digunakan selama magang kurang lebih 1 bulan dari tanggal 13 Januari 2020 sampai dengan 13 Februari 2020. Penulis melakukan pengumpulan data dengan cara pengamatan dan melakukan wawancara terhadap pegawai dan staff, pengamatan lewat internet, buku dan sumber-sumber lain yang relevan dengan data yang dibutuhkan.

\section{HASIL DAN PEMBAHASAN \\ Analisis Unsur Pengendalian Intern pada Dinas Kominfo Kabupaten Semarang Lingkungan Pengendalian}

Kondisi lingkungan pengendalian Dinas Kominfo Kabupaten Semarang secara umum telah cukup memadai, dinas kominfo telah memelihara lingkuangan pengendalian yang efektif serta menimbulkan perilaku positif dan kondusif. Melalui penerapan aturan mengenai standar perilaku etis yang akan memberi kerangka perilaku pada seluruh pegawai. Terlihat dari pelaksanaan dari setiap kegiatan yang ada di lingkungan dinas yang dilakukan oleh pegawai-pegawai yang berkompeten dalam bidangnya masing-masing. Hal tersebut menandakan jika perusahaan memiliki karyawan 
yang kompeten dan jujur. Pengendalian yang lain agar Dinas Kominfo Kabupaten Semarang menghasilkan pertanggungjawaban laporan keuangan yang dapat dipercaya dan diandalkan. Maka dari itu, Dinas Kominfo Kabupaten Semarang rutin mengikutsertakan pegawainya dalam Bimbingan Teknis (bimtek), dan pendidikan serta pelatihan (diklat) berjenjang.

Kepemimpinan di Dinas Kominfo Kabupaten Semarang mencerminkan sistem pengendalian yang baik, dimana pimpinan selalu memberikan arahan, motivasi dan contoh langsung bagi para pegawai. Dengan arahan yang diberikan, akan memudahkan para pegawai dalam mengerjakan pekerjaannya dan akan semakin kompak. Selain itu, pimpinan juga memperhatikan setiap pegawainya, dari mengevaluasi kinerja setiap pegawai dan menjalin interaksi dengan seluruh bawahannya. Untuk pelajar yang sedang melakukan praktik kerja lapangan juga diperhatikan perkembangannya, mengarahkan alur yang harus dikerjakan dan juga berinteraksi dengan para pelajar PKL.

Pembentukan struktur organisasi serta metode pendelegasian wewenang dan tanggungjawab yang ada pada Dinas Kominfo Kabupaten Semarang menggambarkan sistem pengendalian yang cukup baik. Dilihat dari pembagian tugas yang ada telah secara jelas dikomunikasikan kepada setiap pegawai yang ada. Dinas Kominfo Kabupaten Semarang memiliki hubungan kerja yang baik dengan instransi pemerintah yang mengelola anggaran, akuntansi dan perbendaharaan. Maka semua hal tersebut mengindikasikan bahwa nilai-nilai lingkungan pengendalian yang baik telah terinternalisasi dan terimplementasi dengan baik pada Dinas Kominfo Kabupaten Semarang.

\section{Penilaian Risiko}

Pelaksanaan penilaian risiko oleh Dinas Kominfo Kabupaten Semarang, kepala Plt. dinas mengidentifikasi, menganalisis risiko dan menentukan tindakan apa yang akan diambil untuk menghadapi risiko-risiko yang dapat menghambat adanya visi misi dan tujuan dari Dinas Kominfo Kabupaten Semarang. Hal ini telah sesuai dengan PP no 60 Tahun 2008 yang berisi tentang Sistem Pengendalian Intern Pemerintah (SPIP), dengan begitu dapat dikatakan bahwa penilaian risiko pada Dinas Kominfo Kabupaten Semarang secara umum berjalan baik. Namun dengan adanya penilaian risiko ini. masih terdapat risiko vang harus dihadapi. seperti penilaian dari publik tentang pelayanan yang diberikan oleh Dinas Kominfo Kabupaten Semarang, kinerja hardware yang semakin lama menurun, dan kerusakan aset teknologi.

Temuan yang didapati di Dinas Kominfo Kabupaten Semarang ternyata kurang memperhatikan latar pendidikan pegawainya, sehingga tidak semua pegawai yang melakukan tugas pokok pengawasan, penganggaran dan perencaraan berlatar belakang pendidikan ekonomi, khususnya akuntansi. Dengan demikian resiko yang mungkin masih akan timbul adalah adanya salah pencatatan atau pengidentifikasian transaksi.

\section{Kegiatan Pengendalian}

Sesuai dengan unsur-unsur pengendalian intern PP No 60 Tahun 2008, kegiatan pengendalian adalah prosedur atau kebijakan yang dilaksanakan agar dapat membantu memastikan dilaksanakannya arahan dari pimpinan instansi untuk mengurangi resiko yang telah terlebih dahulu diidentifikasi selama proses penilaian risiko. Pimpinan Dinas Kominfo Kabupaten Semarang telah efektif melakukan kegiatan pengendalian yang diperlukan untuk menangani setiap risiko dan memberikan arahan. Kegiatan pengendalian yang telah dilaksanakan oleh Dinas Kominfo Kabupaten Semarang adalah dengan mengevaluasi kinerja para pegawainya, meningkatkan kualitas sumber daya manusia dengan pembinaan seperti mengikutsertakan para pegawainya untuk bimbingan teknis maupun diklat secara berjenjang.

Dinas Kominfo Kabupaten Semarang terdapat pula pemisahan fungsi yang dilakukan berdasarkan tugas pokok dan fungsi sesuai dengan Peratutan Bupati Nomor 8 Tahun 2019, tentang Perubahan Atas Peraturan Bupati Semarang Nomor 52 Tahun 2016 Tentang Kedudukan, Susunan Organisasi, Tugas dan Fungsi, Tata Kerja, Dan Perincian Tugas Perangkat Daerah Kabupaten Semarang. Kegiatan secara berkala terus dievaluasi untuk memastikan bahwa kegiatan tersebut masih sesuai dan masih berfungsi sesuai apa yang diharapkan. Pengendalian yang dilakukan yaitu dengan memisahkan setiap fungsi para pegawai, pada Dinas Kominfo terdapat 4 bidang yaitu bidang sekretariat, bidang komunikasi dan informasi publik, bidang aplikasi dan informatika, dan bidang persandian dan statistik. Dimana pada bidang sekretariat dibagi menjadi beberapa subbagian, diantaranya 1). subbagian perencanaan dan evaluasi: 2). subbagian 
keuangan dan aset; dan 3). subbagian umum dan kepegawaian. Setiap kasubag mempunya tugas pokok dan fungsi masing-masing.

\section{Informasi dan Komunikasi}

Dinas Kominfo Kabupaten Semarang telah menerapkan unsur informasi yang tepat dan komunikasi secara baik untuk menunjang sistem pengendalian intern dan manaemen yang sehat. Sarana komunikasi yang digunakan ada berbagai macam, baik berupa buku pedoman kebijakan, memorandum, petunjuk teknis, surat edaran, papan pengumunan, situs internet dan e-mail, maupun berkomunikasi lewat grup Whatsapp yang telah dibuat serta berkomunikasi secara lisan (tatap muka). Dinas Kominfo Kabupaten Semarang juga mempunyai situs web yang bersifat terbuka serta dapat diakses oleh masyarakat luas yang dapat memberikan masukan signifikan terhadap kualitas pelayanan instansi tersebut.

\section{Pemantauan}

Pemantauan harus dapat menilai kualitas kinerja dari waktu ke waktu dan memastikan bahwa rekomendasi hasil audit dan reviu lainnya dapat segara ditindak lanjuti. Pemantauan pada Dinas Kominfo Kabupaten Semarang telah berjalan dengan baik, dengan adanya model pemantauan yang berupa evaluasi pembuatan dan pelaksanaan kebijakan, adanya sosialisasi SOP serta mengevaluasi SOP. Evaluasi kegiatan diselenggarakan melalui penilaian dari pihak pengawas internal (instansi) atau pihak eksternal dari BPK. Evaluasi yang dilakukan Dinas Kominfo Kabupaten Semarang dalam bentuk pemeriksaan reguler sebagai sistem peringatan dini terhadap pelaksaan kegiatan di dinas, dengan menerbitkan Laporan Hasil Pemeriksaan (LHP). Pemantauan dilakukan secara periodik.

Berikut merupakan ringkasan pelaksanaan setiap unsur yang ada dalam Sistem Pengendalian Intern Pemerintah (SPIP) pada Dinas Komuninfo Kabupaten Semarang, dapat dilihat pada Tabel 1.
Tabel. 1

Pelaksanaan Sistem Pengendalian Intern Pemerintah (SPIP) pada Dinas Kominfo Kabupaten Semarang

\begin{tabular}{|c|c|c|}
\hline No & Unsur SPIP & $\begin{array}{c}\text { Pelaksanaan } \\
\text { Lapangan }\end{array}$ \\
\hline 1. & $\begin{array}{c}\text { Lingkungan } \\
\text { Pengendalian }\end{array}$ & $\sqrt{ }$ \\
\hline 2. & $\begin{array}{c}\text { Penilaian } \\
\text { Risiko }\end{array}$ & $\sqrt{ }$ \\
\hline 3. & $\begin{array}{c}\text { Kegiatan } \\
\text { Pengendalian }\end{array}$ \\
\hline 4. & $\begin{array}{c}\text { Informasi \& } \\
\text { Komunikasi }\end{array}$ & $\sqrt{ }$ \\
\hline 5. & Pemantauan & $\sqrt{ }$ \\
\hline
\end{tabular}

Sumber : hasil penelitian, 2020

Apabila 5 faktor diatas dilakukan secara baik oleh setiap instansi pemerintahan maka tujuan dari pemerintah akan tercapai secara maksimal. Maka dari itu, dengan menerapkan unsur-unsur diatas secara efektif, Dinas Kominfo Kabupaten Semarang juga dapat mencapai tujuan secara efektif serta efisien, keandalan pelaporan keuangan, pengamanan aset negara, dan ketaatan terhadap peraturan perundang-undangan.

\section{Dampak Pengendalian Intern pada Dinas Kominfo Kabupaten Semarang}

Dampak yang didapat dalam pengendalian internal pada Dinas Kominfo Kabupaten Semarang yaitu sebagai berikut:

\section{Keandalan Laporan Keuangan}

Dinas Kominfo Kabupaten Semarang dalam penyusunan Laporan Keuangan berpedoman pada prinsip akuntansi yang berlaku umum, dan diakhir tahun melaksanakan evaluasi kinerja. Selain itu, dalam penyusunan Laporan Keuangan dilakukan oleh pegawai yang kualitasnya mempuni dalam bidang keuangan dan selalu menerapkan pengendalian intern dalam pelaksanaan tugas dan fungsinya.

\section{Pengamanan Aset Negara}

Dinas Kominfo Kabupaten Semarang telah berupaya mengamankan aset negara dengan berjalan secara tertib, akuntabel, dan dengan nilai yang wajar. Dari upaya pengendalian aset yang beresiko akan hilang, rusak, dicuri, secara fisik telah diamankan. 
3. Efektivitas dan Efisiensi Kegiatan Instansi Pemerintah

Pengelolaan sumber daya telah cukup optimal di Dinas Kominfo Kabupaten Semarang karena di instansi telah menrapkan sistem pengendalian intern sesuai dengan PP No. 60 Tahun 2008, sehungga dalam pencapaian tujuan penyelenggaraan pemerintah daerah yang dilakukan Dinas Kominfo Kabupaten Semarang dapat dikatakan efektif.

4. Ketaatan Dalam Peraturan PerundanganUndangan

Dinas Kominfo Kabupaten Semarang telah berusaha menaati peraturan hukum yang berlaku mengenai aturan tentang kegiatan pengawasan yang telah ditetapkan. Pimpinan juga sudah memberikan arahan dan teladan yang baik mengenai etika dalam menjalankan tugas sesuai dengan tanggung jawab dan wewenang masing-masing pegawai.

Berdasarkan dari hasil penelitian yang dijelaskan diatas, menunjukkan bahwa penerapan Sistem Pengendalian Intern Pemerintah (SPIP) di Dinas Kominfo Kabupaten Semarang telah dilaksanakan dengan baik, bahwa Dinas Kominfo Kabupaten Semarang telah menerapkan prinsip dalam setiap faktor dalam pengendalian intern menurut Peraturan Pemerintah Nomor 60 Tahun 2008. Dengan menerapkan Sistem Pengendalian Intern Pemerintah (SPIP) maka pengelolaan dan pengawasan keuangan daerah dapat berjalan baik serta dapat mendukung penyelenggaraan pemerintah yang efektif dan juga efisien. Maka dari itu, dapat dikatakan bahwa Sistem Pengendalian Intern Pemerintah (SPIP) pada Dinas Kominfo Kabupaten Semarang telah berjalan dengan cukup optimal dalam mendukung terciptanya good governance.

Terdapat kekurangan dari Dinas Kominfo Kabupaten Semarang yang ternyata kurang memperhatikan latar pendidikan pegawainya, sehingga tidak semua pegawai yang melakukan tugas pokok pengawasan, penganggaran dan perencaraan berlatar belakang pendidikan ekonomi, khususnya akuntansi. Dengan demikian resiko yang mungkin masih akan timbul adalah adanya salah pencatatan atau pengidentifikasian transaksi. Jumlah pegawai di Dinas Kominfo Kabupaten Semarang yang cukup lengkap namun menampung cukup banyak siswa magang mengakibatkan pelaksanaan tugas siswa magang jadi belum sepenuhnya efisien dan kebanyakan menganggur. Dalam sarana dan prasarana yang ada di Dinas Kominfo Kabupaten Semarang, seperti fasilitas bangunan atau gudang untuk dokumen dan barang-barang kurang tercukupi karena barang-barang yang tergeletak disudut bawah gedung Dinas Kominfo Kabupaten Semarang.

\section{KESIMPULAN DAN SARAN}

Berdasarkan hasil penelitian yang penulis lakukan pada Dinas Kominfo Kabupaten Semarang, dan juga berdasar dari pembahasan yang telah dikemukakan mengenai penerapan Sistem Pengendalian Intern Pemerintah pada Dinas Kominfo Kabupaten Semarang, maka penulis menarik kesimpulan bahwa secara umum Sistem Pengendalian Intern Pemerintah (SPIP) pada Dinas Kominfo Kabupaten Semarang sudah berjalan dengan baik, karena penerapannya telah sesuai dengan unsur-unsur dalam SPIP yang telah ditetapkan berdasar PP No. 60 Tahun 2008. Sistem dan prosedur pada Dinas Kominfo Kabupaten Semarang juga sudah cukup memadai, ditunjang dengan pegawai yang kompeten dibidangnya membuat tingkat kesalahan atas pengendalian dapat diatasi, jumlah pegawai di Dinas Kominfo Kabupaten Semarang cukup lengkap, namun dinas menerima cukup banyak pelajar magang sehingga mengakibatkan pelaksanaan tugas belum sepenuhnya efisien.

Adapun saran yang dapat penulis berikan terkait dengan hasil dari penelitian diatas adalah sebagai berikut:

1. Diharapkan pimpinan Dinas Kominfo Kabupaten Semarang dapat terus menjaga serta meningkatkan komitmen yang lebih baik sehingga terciptanya good governance.

2. Sistem pengendalian intern yang ada pada Dinas Kominfo Kabupaten Semarang diharapkan dipertahankan dan bahkan lebih ditingkatkan sehingga dalam pencapaian tujuan bisa lebi optimal.

3. Perlu adanya perhatian khusus dalam sarana dan prasarana yang ada di Dinas Kominfo Kabupaten Semarang, seperti fasilitas bangunan atau gudang untuk dokumen dan barang-barang.

4. Membatasi penerimaan pelajar yang akan melakukan kegiatan magang agar pekerjaan yang diberikan lebih efektif dan efisien. 


\section{DAFTAR PUSTAKA}

Armando, G. (2013). Pengaruh sistem pengendalian intern pemerintah dan pengawasan keuangan daerah terhadap nilai informasi laporan keuangan pemerintah (Studi Empiris pada SKPD di Kota Bukittinggi). Jurnal akuntansi, 1 (1).

Bimantara, Z. A., \& Handayani, S. R. (2017). Analisis Pengendalian Intern Dalam Sistem Akuntansi Penerimaan Kas Pelayanan Rawat Inap Dan Rawat Jalan Pasien Umum (Studi Pada Rumah Sakit Ibnu Sina Bojonegoro). Jurnal Administrasi Bisnis, 45(1), 203-209.

Deddi, Iswahyudi, \& Maulidah. (2012). Akuntansi Pemerintahan. Jakarta: Salemba Empat.

Hamidah, R. T. (2014). Pengaruh Pelaksanaan Sistem Pengendalian Intern Pemerintah dan Sumber Daya Manusia Terhadap Pengamanan Aset Negara (Studi Empiris Pada Kementerian Perindustrian Wilayah Jawa Sumatera). Jurnal Akuntansi, 2(1).

Harahap, S., \& Syafri. (2004). Teori Akuntansi. Jakarta: PT Raja Grafindo Persada.

Ismani, 1., Istinigrum, A. A., Nugroho, M. A., \& Pustikaningsih, A. (2014). Implementasi Sistem Pengendalian Intern Pemerintah di Universitas Negeri Yogyakarta. Jurnal Economia, 10(1), 24-37.

KOMINFO. (2011, Mei 31). Retrieved from kominfo.go.id:

https://kominfo.go.id/content/detail/457/sejarah/0/pa ge

Krismiaji. (2010). Sistem Informasi Akuntansi. Yogyakarta: AMP YKPN.

Latif, Z. (2017). Dinas Komunikasi dan Informatika Pemerintah Daerah Kabupaten Semarang. Retrieved from https://diskominfo.semarangkab.go.id: https://diskominfo.semarangkab.go.id/visi-misi/

Mokoginta, N., Lambey, L., \& Pontoh, W. (2017). Pengaruh Sistem Pengendalian Intern dan Sistem Akuntansi Keuangan Daerah terhadap Kualitas Laporan Keuangan Pemerintah. Jurnal Riset Akuntansi, 12 (2).

Mulyadi. (2001). Sistem Akuntansi. Jakarta: Salemba Empat.

Peraturan Bupati Nomor 8 Tahun 2019 Tentang Perubahan Atas Peraturan Bupati Semarang Nomor 52 Tahun 2016 Tentang Kedudukan, Susunan Organisasi, Tugas Dan Fungsi, Tata Kerja, Dan Perincian Tugas Perangkat Daerah Kabupaten Semarang. (2019).

Peraturan Pemerintah Nomor 60 Tahun 2008 Tentang Sistem Pengendalian Intern Pemerintah. (2008).
Purnomo, B. S. (2014). Pengaruh sistem pengendalian internal dan kekuatan koersif terhadap kualitas laporan keuangan Pemerintah Daerah. Jurnal Riset Akuntansi dan Keuangan, 2(1), 276-288.

Rama, \& Jones. (2016, Maret 17). Retrieved from http://fernandesocto.blogspot.co.id: http://fernandesocto.blogspot.co.id/2013/02/sistemp engendalian-intern.html

Ristanti, N. M., Sinarwati, N. K., \& Sujana, S. E. (2014). Pengaruh Sistem Pengendalian Intern, Pengelolaan Keuangan Daerah dan Komitmen Organisasi terhadap Penerapan Good Governance (Studi Kasus pada Satuan Kerja Perangkat Daerah Kabupaten Tabanan). JIMAT (Jurnal Ilmiah Mahasiswa Akuntansi) Undiksha, 2(1).

Sujarweni, \& Wiratna. (2015). Akuntansi Sektor Publik. Yogyakarta: Penerbit Pustaka Baru Press.

Suliyanto, S. E., \& MM, S. (2017). Metode Penelitian Kuantitatif. 